\title{
Pengaruh Penggunaan Aplikasi Google Meet terhadap Hasil Belajar
}

\author{
Bayu Fitra Prisuna* \\ Fakultas Tarbiyah dan Ilmu Keguruan, Institut Agama Islam Negeri Pontianak \\ Jl. Letjend Suprapto, Benua Melayu Darat, Kota Pontianak, Kalimantan Barat, Indonesia, 78113 \\ *Corresponding Author. e-mail: bayufitraprisuna@ iainptk.ac.id
}

\begin{abstract}
Abstrak
Google meet merupakan sebuah aplikasi video conference yang salah satunya dapat digunakan untuk proses kegiatan belajar mengajar. Penelitian ini bertujuan untuk mengetahui seberapa besar pengaruh penggunaan aplikasi Google Meet terhadap hasil belajar mahasiswa pada mata kuliah metodologi penelitian kuantitatif. Penelitian menggunakan pendekatan kuantitatif dengan jenis penelitian preEksperimen, dengan desain penelitian adalah one group pretest-posttest design. Populasi penelitian adalah seluruh mahasiswa semester $\mathrm{V}$ pada mata kuliah metodologi penelitian kuantitatif yang berjumlah 30 orang. Pengambilan sampel menggunakan teknik total sampling. Jenis instrumen yang digunakan adalah pretest dan posttest hasil belajar berupa soal pilihan ganda. Berdasarkan hasil penelitian dan pembahasan dapat ditarik kesimpulan bahwa terdapat pengaruh yang signifikan antara penggunaan aplikasi Google Meet terhadap hasil belajar mahasiswa sebesar $51.4 \%$. Rata-rata keseluruhan hasil posttest lebih besar dibandingkan nilai rata-rata keseluruhan hasil pretest. Nilai rata-rata $N$-Gain score pada mahasiswa sebesar $56.9 \%$, sehingga termasuk ke dalam kategori "cukup efektif". Kegiatan pembelajaran mahasiswa menggunakan aplikasi Google Meet berlangsung relatif kondusif walaupun terdapat beberapa kendala seperti jaringan tidak stabil, dan kuota internet yang terbatas pada saat perkuliahan sedang berlangsung.
\end{abstract}

Kata Kunci: aplikasi Google Meet, hasil belajar

\section{The Effect of Using Google Meet Applications on Learning Outcomes}

\begin{abstract}
Google meet is a video conferencing application, one of which can be used for teaching and learning activities. This study aims to determine how much influence the use of the Google Meet application has on student learning outcomes in quantitative research methodology courses. The research uses a quantitative approach with the type of pre-experimental research, with the research design being a one group pre-testpost-test design. The research population is all students in the fifth semester of the quantitative research methodology course, totalling 30 people. Sampling using total sampling technique. The type of instrument used is pre-test and post-test learning outcomes in the form of multiple-choice questions. Based on the results of research and discussion, it can be concluded that there is a significant influence between the use of the Google Meet application on student learning outcomes by 51.4\%. The overall average of the posttest results is greater than the average value of the overall pre-test results. The average N-Gain score for students is 56.9\%, so it is included in the "fairly effective" category. Student learning activities using the Google Meet application were relatively conducive even though there were several obstacles such as unstable networks, and limited internet quota during lecture.
\end{abstract}

Keywords: Google Meet application, learning outcomes

How to Cite: Prisuna, B. F. (2021). Pengaruh penggunaan aplikasi google meet terhadap hasil belajar. Jurnal Penelitian Ilmu Pendidikan, 14(2), 137-147. doi: https://doi.org/10.21831/jpipfip.v14i1.39160.

Received 03-03-2021; Received in revised from 26-04-2021; Accepted 19-07-2021

This is an open-access article under the CC-BY-SA license. 


\section{PENDAHULUAN}

Pendidikan era revolusi 4.0 diharapkan mampu mewujudkan pendidikan cerdas melalui peningkatan dan pemerataan kualitas pendidikan. Greenstein (2012), mengemukakan bahwa pendidikan di era revolusi industri 4.0 dipandang sebagai pengembangan tiga kompetensi besar abad ke 21, yakni kompetensi berpikir, bertindak, dan hidup di dunia. Sejalan dengan itu, Revolusi industri 4.0 ditandai dengan berkembangnya internet of atau for things yang diikuti teknologi baru dalam data dan sains, kecerdasan buatan, robotik, cloud, cetak tiga dimensi, dan teknologi nano (Ghufron, 2018). Bagi perguruan tinggi tantangan pada era ini bukan hanya pada pemerataan pendidikan saja melainkan kompetensi dari lulusan juga harus menjadi perhatian. Hal ini mengakibatkan para lulusan akan menghadapi tantangan berat dari resesi global yang disebabkan oleh krisis Covid-19 (Burgess \& Sievertsen, 2020). Menristekdikti (2018) menyatakan bahwa dalam menghadapi era revolusi 4.0 ada beberapa hal yang harus menjadi perhatian dan akan dilaksanakan salah satunya adalah persiapan sistem pembelajaran yang lebih inovatif di perguruan tinggi seperti penyesuaian kurikulum pembelajaran, dan meningkatkan kemampuan mahasiswa. Penyesuaian kurikulum pembelajaran terkait data Information Technology (IT), Operational Technology (OT), Internet of Things (IoT), dan Big Data Analitic, mengintegrasikan objek fisik dan digital. Sedangkan untuk menghasilkan lulusan perguruan tinggi yang kompetitif dan terampil maka kemampuan mahasiswa difokuskan terutama dalam aspek data literacy, technological literacy, and human literacy. Berkaitan dengan persiapan sistem pembelajaran yang lebih inovatif, hal ini sangat relevan dengan kondisi pendidikan di dunia khususnya di Negara Indonesia yang sedang dilanda bencana non alam yaitu Corona Virus Disease 2019 (Covid-19).

Bencana non alam yang diakibatkan oleh penyebaran Corona Virus Disease 2019 (Covid-19) yang sedang melanda hampir di seluruh penjuru dunia sangat memberi pengaruh yang besar terhadap dunia pendidikan. "Recent research has shown that the COVID-19 pandemic sent shockwaves throughout the entire education system on an unprecedented global scale" (Johnson, Veletsianos, \& Seaman, 2020). Menurut pantauan dari UNICEF, 186 negara saat ini telah menerapkan penutupan berskala nasional dan delapan (8) negara menerapkan penutupan lokal. Hal ini berdampak pada sekitar $98.5 \%$ populasi siswa di dunia (UNESCO, 2020). Kebijakan yang diambil sebagian besar negara termasuk negara Indonesia dengan meniadakan seluruh aktivitas pendidikan, mengharuskan pemerintah memberikan alternatif solusi bagi permasalahan yang dialami saat ini. Gewin (2020), menyatakan bahwa banyak universitas di seluruh dunia telah menunda atau membatalkan berbagai kegiatan seperti campus event, seminar, konferensi, kompetisi olahraga, dan kegiatan lainnya. Gewin juga menambahkan bahwa universitas telah bergerak cepat untuk mentransmisikan berbagai program agar pembelajaran tetap berlangsung. Sejalan dengan hal ini, UNESCO (2020) merekomendasikan penggunaan program pembelajaran jarak jauh atau distance learning dan menggunakan aplikasi atau platform pendidikan yang dapat digunakan di sekolah atau perguruan tinggi untuk menjangkau peserta didik dan mahasiswa dari jarak jauh. Adapun beberapa platform Pendidikan yang dapat digunakan merujuk pada 96 Negara yang telah menggunakan platform Pendidikan tersebut diantaranya: perpustakaan online, siaran edukasi di televisi, video simulasi, serta program online lainnya (Basilaia, Dgebuadze, Kantaria, \& Chokhonelidze, 2020). Berbagai jenis platform pembelajaran jarak jauh dapat digunakan sebagai alternatif untuk menghadapi permasalahan saat ini.

Menjawab tantangan tersebut maka sebagai pendidik profesional dituntut menjadi problem solver. Pendidik merupakan problem solver juga disampaikan oleh Vokatis \& Zhang, (2016) "The teachers' identity is multifaceted, as vision-driven professional knowledge builders, problem solvers, co-learners with students, and innovative collaborators with colleagues". Meskipun aktivitas pembelajaran tatap muka di kampus ditiadakan pada masa pandemi saat ini, diharapkan pendidik tetap menjaga profesionalitas dalam melaksanakan tanggung jawab. Daya kreatifitas pendidik sangat menentukan dalam tercapainya tujuan Pendidikan Nasional yang tercantum pada Undang-Undang RI No. 20 (2003) tentang Sistem Pendidikan Nasional pada pasal 3. Tujuan pendidikan nasional adalah mengembangkan potensi peserta didik agar menjadi manusia yang beriman dan bertakwa kepada Tuhan Yang Maha Esa, berakhlak mulia, sehat, berilmu, cakap, kreatif, mandiri, dan menjadi warga negara yang demokratis serta bertanggung jawab. Bahkan pemerintah pun sedang berinovasi untuk mencari formula yang tepat dalam proses kegiatan belajar mengajar pada masa pandemi saat ini. 
Model pembelajaran jarak jauh masih menjadi pilihan utama apalagi untuk daerah-daerah yang berada pada zona merah yaitu daerah yang beresiko tinggi penularan virus corona penyebab covid-19. Metode yang cocok diterapkan pada kondisi ini adalah dengan menggunakan metode daring seperti perkuliahan yang dilakukan saat ini, pembelajaran yang disampaikan akan tetap berlangsung dan seluruh pelajar tetap berada di rumah masing-masing dalam keadaan aman. Hal ini sejalan dengan Surat Edaran No.4 tahun 2020 dari Menteri Pendidikan dan Kebudayaan yang menganjurkan seluruh kegiatan di institusi pendidikan harus jaga jarak dan seluruh penyampaian materi akan disampaikan di rumah masing-masing. Hal ini sejalan dengan Surat Edaran No.4 tahun 2020 dari Menteri Pendidikan dan Kebudayaan yang menganjurkan seluruh kegiatan di institusi pendidikan harus jaga jarak dan seluruh penyampaian materi akan disampaikan di rumah masing-masing.

Berdasarkan pengalaman peneliti pada pertengahan semester genap tahun ajaran 2019/2020 di Fakultas Tarbiyah dan Ilmu Keguruan Institut Agama Islam Negeri Pontianak, pembelajaran dilakukan secara daring dengan menggunakan aplikasi whatsapp. Pada pembelajaran mahasiswa cenderung diberikan tugas individu atau kelompok via group whatsapp oleh dosen. Akan tetapi dianggap kurang efektif dalam tercapainya tujuan pembelajaran. Hal ini tergambarkan dari hasil ujian akhir semester mahasiswa cenderung rendah. Daheri, Juliana, Deriwanto, \& Amda (2020) menyatakan bahwa "penggunaan whatsapp sebagai media pembelajaran daring kurang efektif dalam mencapai tujuan pembelajaran, salah satu faktornya adalah kurangnya penjelasan yang komprehensif dan sederhana dari guru." Sejalan dengan penelitian yang dilakukan Mardiah, S. (2020) menyatakan bahwa peserta didik beranggapan bahwa belajar bahasa Inggris melalui aplikasi whatsApp tidak memberikan hasil yang maksimal, karena mereka kesulitan dalam memahami materi ajar yang diberikan oleh guru. Berdasarkan hal ini peneliti melakukan inovasi dalam memilih media pembelajaran yang digunakan agar tujuan pembelajaran tercapai. Salah satu alternatif media pembelajaran yang dapat digunakan adalah aplikasi Google Meet.

Google Meet (formerly known as Hangouts Meet) is a video-communication service developed by Google (Wikipedia, 2020). Google meet merupakan sebuah aplikasi video conference yang digunakan untuk proses meeting secara online yang dibuat dan dikembangkan oleh Google. Google Meet memungkinkan pengguna untuk mengadakan rapat saat dalam perjalanan, melaksanakan kegiatan belajar mengajar dan kelas pelatihan virtual. Google Meet memiliki fitur yang bisa dimanfaatkan untuk melakukan panggilan video berkualitas tinggi hingga mencapai 250 orang. Selama tahun 2020 pandemi COVID-19, penggunaan Google Meet tumbuh antara Januari hingga April 2020, dengan 100 juta pengguna sehari mengakses Google Meet.

adalah single (tunggal) tanpa ada spasi tambahan antar paragraf. Jenis huruf yang digunakan Times New Roman ukuran 11.

“...Google Meet is considered as a safe environment in online teaching, and it is highly recommended during the pandemic outbreak. It is considered as a potential solution in teaching during the shutdown period. The availability of GM has given all teachers and peers the self-sensing of security and an immediate communication tool when the city of Dubai is the contamination status. Google Meets has several advantages over other means of communication. First, it is an application on smartphones and laptops. This fact helps The British University in Dubai (BUiD) students to join classes easily using their own smartphones. The second important factor is that the links that are provided within each class time can be used several times which enables the students to relate to their teachers any time during the day. The last crucial factor is that students are more confident, and the feeling of fear is reduced to its minimum level (Anhusadar, Salloum, Hassanein, \& Shaalan, 2020: 13)."

Hal ini membuktikan bahwa Google Meet dianggap mampu menjawab permasalahan yang dialami oleh sebagian besar pelajar yang mengharuskan melakukan pembelajaran jarak jauh. Wiratama (2020) menyatakan bahwa pada masa pandemi covid-19 ini pemanfaatan aplikasi Google Meet dalam perkuliahan konsep PKN SD mahasiswa PGSD Unirow sebagai media $e$-learning terbukti efektif. Sejalan dengan penelitian yang dilakukan Setyawan, Aznam, Paidi, Citrawati, \& Kusdianto (2020: 3933) mengemukakan hasil penelitiannya, yakni, "Google Meet group students get higher knowledge build scores than Whatsapp groups and Schoology groups. Besides, there are significant differences in the scores of learning outcomes between the Google Meet group and the students 
Whatsapp group and Schoology group".

Penggunaan aplikasi Google Meet dalam pembelajaran daring diharapkan mampu meningkatkan hasil belajar mahasiswa pada mata kuliah metodologi penelitian kuantitatif. Seperti penelitian yang dilakukan oleh Nuriansyah (2020) bahwa platform Google Meet bisa meningkatkan hasil belajar mahasiswa, dikarenakan dosen selalu melakukan perkuliahan tatap muka secara daring. Perkuliahan tatap muka secara daring dibutuhkan oleh mahasiswa untuk menerima ilmu yang disampaikan oleh dosen secara maksimal. Seperti kita ketahui pengetahuan mahasiswa terhadap metodologi penelitian kuantitatif harus komprehensif agar dapat memahami dan sekaligus mempraktekkan pengetahuan tersebut pada saat semester akhir ketika melakukan penelitian dengan pendekatan kuantitatif. Adapun kompetensi yang harus dimiliki peneliti kuantitatif menurut Sugiyono (2008) sebagai berikut: memahami wawasan yang luas dan mendalam tentang bidang pendidikan yang akan diteliti; mampu melakukan analisis masalah secara akurat, sehingga dapat ditemukan masalah penelitian pendidikan yang betul-betul masalah; mampu menggunakan teori pendidikan yang tepat sehingga dapat digunakan untuk memperjelas masalah yang diteliti, dan merumuskan hipotesis penelitian; memahami berbagai jenis penelitian kuantitatif, seperti metode survei, eksperimen, action research, exposi research, ex post facto, evaluasi dan $\mathrm{R} \& \mathrm{D}$; memahami teknik-teknik sampling, mampu menghitung, memilih jumlah sampel yang representatif dengan sampling error tertentu; mampu menyusun instrumen tes maupun non tes untuk mengukur dan menguji variabel yang diteliti; mampu mengumpulkan data melalui angket atau wawancara; mampu menyajikan data, menganalisis data secara kuantitatif untuk menjawab rumusan masalah dan menguji hipotesis penelitian; mampu memberikan interpretasi terhadap data hasil penelitian maupun hasil uji hipotesis; mampu membuat laporan secara sistematis; mampu membuat abstrak hasil penelitian; mampu mengkomunikasikan hasil penelitian kepada orang banyak. Berdasarkan latar belakang di atas, maka dilakukan penelitian pre-Eksperimen dengan tujuan mengetahui seberapa besar pengaruh penggunaan aplikasi Google Meet terhadap hasil belajar mahasiswa pada mata kuliah metodologi penelitian kuantitatif Program Studi Bimbingan Konseling Islam kelas VA IAIN Pontianak

\section{METODE}

Pendekatan yang digunakan dalam penelitian ini adalah pendekatan kuantitatif dengan jenis penelitian pre-Eksperimen. Penelitian ini menggunakan satu kelas sebagai subjek penelitian dengan mengacu pada desain penelitian one group pretest-posttest design. Populasi dalam penelitian ini adalah seluruh mahasiswa Program Studi Bimbingan Konseling Islam IAIN Pontianak kelas VA sebanyak 30 orang. Sampel dalam penelitian ini adalah seluruh anggota populasi dengan pengambilan sampel menggunakan teknik Total Sampling yaitu teknik pengambilan sampel di mana jumlah sampel sama dengan jumlah populasi (Sugiyono, 2011).

Teknik pengumpulan data menggunakan teknik tes hasil belajar. Instrumen pengumpulan data dalam penelitian ini berupa soal pilihan ganda. Sebelum instrumen digunakan, terlebih dahulu dilakukan validitas kriteria dengan melakukan uji coba lapangan dan selanjutnya dilakukan analisis dengan berbantuan aplikasi SPSS versi 16, di mana dilakukan uji validitas dengan menggunakan korelasi bivariate pearson dan uji reliabilitas dengan guttman split-half coefficient treatment. Selanjutnya seluruh sampel penelitian diberikan pretest hasil belajar berupa soal pilihan ganda sebanyak 20 butir soal dari 38 butir soal yang telah dilakukan validitas kriteria. Setelah sampel diberikan treatment dengan perkuliahan menggunakan aplikasi Google Meet maka selanjutnya sampel tersebut diberikan post-test hasil belajar dengan soal yang sama pada saat pretest sebelumnya namun soal diacak. Data hasil belajar pre-test dan post-test mahasiswa selanjutnya diolah dan dianalisis. Teknik analisis data hasil belajar tersebut meliputi analisis data deskriptif yang menghasilkan tabel distribusi nilai max, min, mean dan standar deviasi sedangkan analisis data inferensial menghasilkan data uji paired sample t test untuk data yang berdistribusi normal dan data uji Wilcoxon untuk data yang berdistribusi tidak normal. Sebelum data dianalisis, terlebih dahulu dilakukan uji prasyarat analisis meliputi uji normalitas dengan menggunakan uji Kolmogorov-smirnov. Data tersebut dianalisis oleh peneliti dengan bantuan aplikasi SPSS versi 16. 
Adapun nilai rata-rata Normalized Gain score ( $N$-Gain score) mahasiswa dapat disandingkan dengan tabel kategori tafsiran efektivitas $N$-Gain pada Tabel 1.

Tabel 1. Kategori Tafsiran Efektivias N-Gain

\begin{tabular}{cc}
\hline Persentase (\%) & Tafsiran \\
\hline$<40$ & Tidak Efektif \\
$40-55$ & Kurang Efektifitas \\
$56-75$ & Cukup Efektifitas \\
$>76$ & Efektifitas \\
\hline Sumber: Hake, 1999 &
\end{tabular}

\section{HASIL DAN PEMBAHASAN}

\section{Hasil}

Kegiatan pembelajaran pada mata kuliah metodologi penelitian kuantitatif di Program Studi Bimbingan Konseling Islam IAIN Pontianak menggunakan aplikasi Google Meet pada semester ganjil tahun ajaran 2020/2021. Awal perkuliahan mahasiswa diberikan pretest berupa soal pilihan ganda sebanyak 20 butir. Hasil pretest tersebut akan dijadikan pembanding dengan nilai posttest yang akan diberikan setelah diberikan treatment berupa perkuliahan dengan menggunakan aplikasi Google Meet sebanyak kurang lebih 14 pertemuan. Adapun salah satu proses treatment yang diberikan dalam penelitian ini dapat dilihat pada Gambar 1.

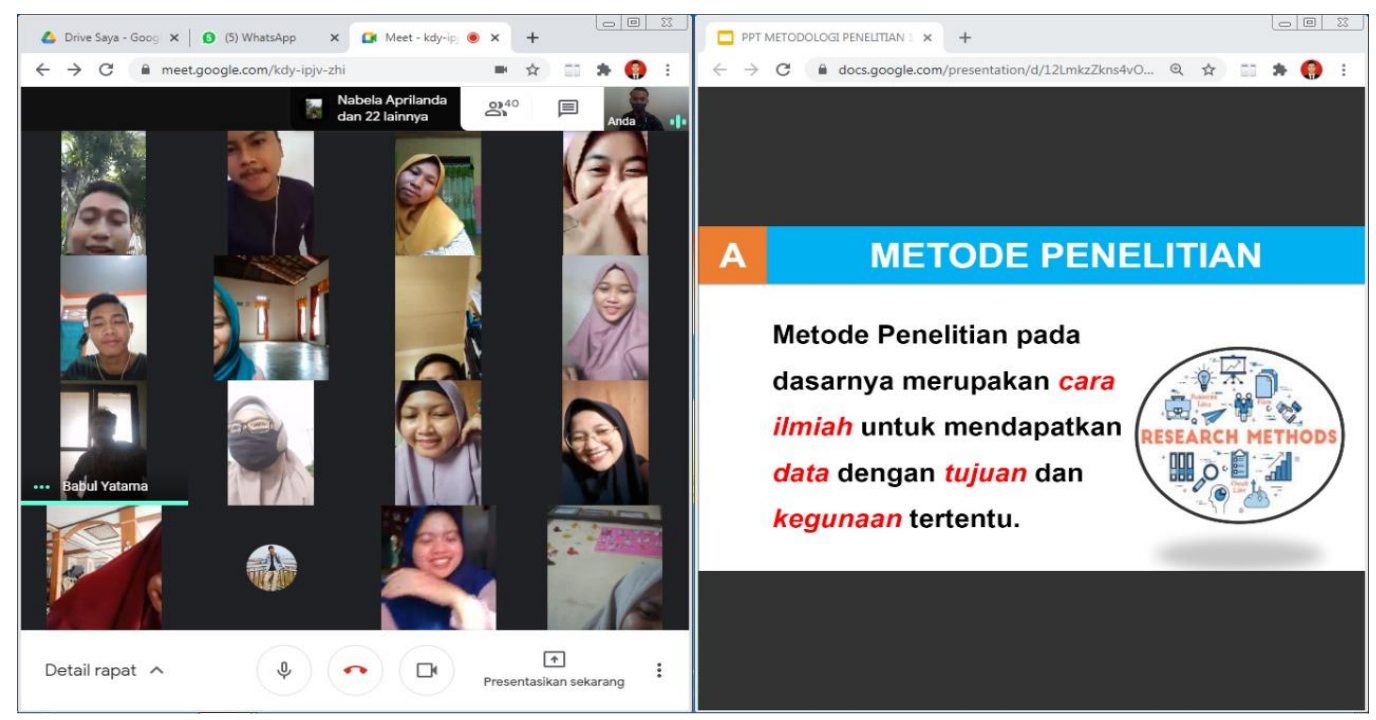

Gambar 1. Treatment dalam penelitian

Gambar 1 menunjukkan proses treatment yang diberikan berupa kegiatan perkuliahan pada mata kuliah metodologi penelitian kuantitatif menggunakan aplikasi Google. Mahasiswa diperkenankan untuk mengajukan pertanyaan, kemudian di akhir sesi perkuliahan dosen melakukan review materi kepada mahasiswa berupa pertanyaan terkait materi perkuliahan untuk mengevaluasi pengetahuan mahasiswa terhadap konsep dasar metodologi penelitian kuantitatif. Setelah kurang lebih 14 kali pertemuan dilakukan perkuliahan via Google Meet, selanjutnya mahasiswa diberikan posttest berupa soal pilihan ganda pula sebanyak 20 butir soal. Setelah itu data hasil pretest dan posttest mahasiswa diolah dan dianalisis menggunakan analisis statistik deskriptif dan analisis statistik inferensial. Dalam analisis statistik deskriptif bertujuan untuk memaparkan dan menggambarkan data penelitian yang diperoleh berupa jumlah data, nilai maksimum, nilai minimum, nilai rata-rata, standar 
deviasi, dan lain-lainnya. Berikut data hasil analisis statistik deskriptif dengan bantuan aplikasi SPSS versi 16.

Tabel 2. Descriptive Statistics

\begin{tabular}{cccccc}
\hline & N & Minimum & Maximum & Mean & Std. Deviation \\
\hline Pre-Test & 30 & 20 & 80 & 51.67 & 13.476 \\
Post-Test & 30 & 60 & 90 & 79.17 & 8.718 \\
Valid N (listwise) & 30 & & & & \\
\hline
\end{tabular}

Sumber: Data primer yang diolah, 2020

Berdasarkan output data pada Tabel 2. Descriptive Statistics di atas menunjukkan bahwa nilai rata-rata pada hasil pretest 51.67 sedangkan nilai rata-rata pada hasil posttest 79.17 . Hal ini menunjukkan bahwa nilai rata-rata keseluruhan hasil posttest lebih besar dibandingkan nilai rata-rata keseluruhan hasil pretest. Selanjutnya data pretest dan posttest yang diperoleh melalui tes hasil belajar, kemudian diolah dan dianalisis dengan menggunakan uji paired sample $t$ test karena sebelumnya telah dilakukan uji normalitas menggunakan uji Kolmogorov-smirnov. Berikut hasil uji normalitas data menggunakan uji Kolmogorov-smirnov dengan bantuan aplikasi SPSS versi 16.

Tabel 3. Test of Normality

\begin{tabular}{lcc}
\hline & Kelas & $\begin{array}{c}\text { Kolmogorov-Smirnov }^{\mathbf{a}} \\
\text { Sig. }\end{array}$ \\
\hline Hasil Belajar & Pre-Test & .080 \\
Mahasiswa & Post-Test & .084 \\
\hline \multicolumn{2}{l}{ Sumber: Data primer yang diolah, 2020 }
\end{tabular}

Berdasarkan output data pada Tabel 3. Test of Normality di atas menunjukkan bahwa nilai signifikansi (Sig.) untuk semua data baik pretest maupun posttest pada uji Kolmogorov-smirnov > 0.05 , maka dapat disimpulkan bahwa data penelitian hasil belajar mahasiswa berdistribusi normal, sehingga persyaratan normalitas telah terpenuhi. Selanjutnya dilakukan uji paired sample t test untuk mengetahui pengaruh penggunaan aplikasi Google Meet terhadap hasil belajar mahasiswa. Berikut hasil uji paired sample t test menggunakan bantuan aplikasi SPSS versi 16.

Tabel 4. Paired Samples Test

\begin{tabular}{|c|c|c|c|c|c|c|c|c|c|}
\hline & & \multirow[t]{2}{*}{ Mean } & \multirow{2}{*}{$\begin{array}{c}\text { Std. } \\
\text { Deviation }\end{array}$} & \multirow{2}{*}{$\begin{array}{l}\text { Std. } \\
\text { Error } \\
\text { Mean }\end{array}$} & \multicolumn{2}{|c|}{$\begin{array}{l}\text { 95\% Confidence Interval } \\
\text { of the Difference } \\
\end{array}$} & \multirow[t]{2}{*}{$\mathbf{t}$} & \multirow[t]{2}{*}{ df } & \multirow{2}{*}{$\begin{array}{l}\text { Sig. (2- } \\
\text { tailed) }\end{array}$} \\
\hline & & & & & Lower & Upper & & & \\
\hline Pair 1 & $\begin{array}{l}\text { Pre-Test } \\
\text { Post-Test }\end{array}$ & -27.500 & 9.446 & 1.725 & -31.027 & -23.973 & -15.946 & 29 & .000 \\
\hline
\end{tabular}

Berdasarkan output data pair 1 pada Tabel 4. Paired Samples Test di atas menunjukkan bahwa nilai sig. ( 2 tailed) sebesar $0.000<0.05$ maka dapat disimpulkan bahwa ada perbedaan ratarata hasil belajar mahasiswa untuk hasil pretest dan posttestnya. Dengan adanya perbedaan rata-rata hasil pretest dan posttest maka dapat disimpulkan bahwa ada pengaruh penggunaan aplikasi Google Meet terhadap hasil belajar mahasiswa. Berdasarkan hipotesis statistik yang telah dirumuskan sebagai berikut.

Ho: Tidak terdapat pengaruh antara penggunaan aplikasi Google Meet terhadap hasil belajar mahasiswa

Ha: Terdapat pengaruh antara penggunaan aplikasi Google Meet terhadap hasil belajar mahsiswa

Ho: $\rho=0$ (berarti tidak ada pengaruh)

Ha: $\rho \neq 0$ (berarti ada pengaruh)

Dari pengujian hipotesis diatas menghasilkan nilai sig. (2 tailed) sebesar $0.000<0.05$ maka dapat ditarik kesimpulan bahwa Ho ditolak dan Ha diterima. Karena Ha diterima maka dengan 
demikian, dapat diartikan bahwa terdapat pengaruh antara penggunaan aplikasi Google Meet terhadap hasil belajar mahasiswa. Selanjutnya dilakukan uji $r$ square untuk mengetahui seberapa besar pengaruh penggunaan aplikasi Google Meet terhadap hasil belajar mahasiswa. Berikut hasil uji $r$ square dengan analisis regresi linier sederhana menggunakan bantuan aplikasi SPSS versi 16.

Tabel 5. Model Summary

\begin{tabular}{ccccc}
\hline Model & R & R Square & $\begin{array}{c}\text { Adjusted R } \\
\text { Square }\end{array}$ & $\begin{array}{c}\text { Std. Error of } \\
\text { the Estimate }\end{array}$ \\
\hline 1 & $.717^{\mathrm{a}}$ & .514 & .496 & 9.56539 \\
\hline
\end{tabular}

Sumber: Data primer yang diolah, 2020

Berdasarkan output data pada Tabel 5. Model Summary di atas menunjukkan bahwa koefisien determinasi ( $R$ Square) sebesar 0.514. Jika diubah ke dalam bentuk persen, maka koefisien determinasi ( $R$ Square) dapat diartikan bahwa pengaruh penggunaan aplikasi Google Meet terhadap hasil belajar mahasiswa sebesar 51.4\%. Selanjutnya dilakukan uji Normalized Gain (N-Gain) bertujuan untuk mengetahui efektifitas aplikasi Google Meet terhadap hasil belajar mahasiswa. Berikut hasil uji N-Gain dengan menggunakan bantuan aplikasi SPSS versi 16.

Tabel 6. Descriptives N-Gain Score

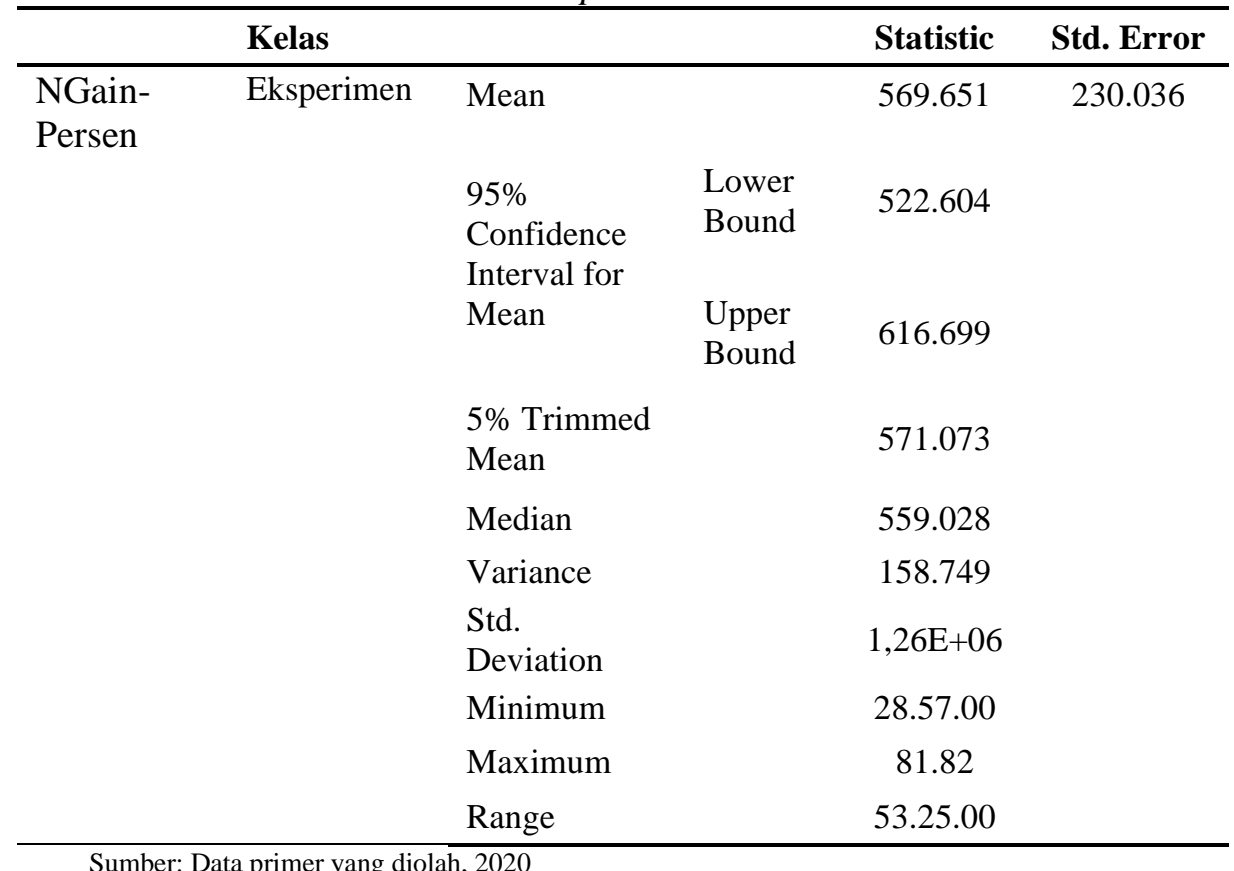

Berdasarkan output data pada Tabel 6. Descriptive N-Gain Score di atas menunjukkan bahwa nilai rata-rata $\mathrm{N}$-Gain score pada mahasiswa adalah sebesar 56.9651 atau dalam persen sebesar 56.9 $\%$ termasuk ke dalam kategori "cukup efektif".

\section{Pembahasan}

Pembelajaran di Institut Agama Islam Negeri Pontianak dilakukan secara daring sejak pertengahan semester genap tahun ajaran 2019/2020 dampak dari adanya pandemi Covid-19. Pembelajaran daring sendiri menjadi hal baru, karena pembelajaran harus dilakukan tanpa tatap muka. "Notably, the Covid19 pandemic has fundamentally changed the teaching practices for schoolteachers who would typically be used to classroom teaching" (Zhang, Wang, Yang, \& Wang, 2020). Kondisi ini menuntut pengajar untuk mencari alternatif solusi agar pembelajaran dapat berjalan dengan baik. Dalam hal ini pendidik dituntut menjadi fasilitator yang bisa menjembatani kepentingan-kepentingan tersebut. Tentu saja melalui usaha-usaha yang bisa diterapkan dalam tercapainya tujuan pembelajaran. Salah satunya 
dalam pemilihan media pembelajaran di masa pandemi seperti saat ini. Berbagai media pembelajaran yang dilakukan secara daring memanfaatkan berbagai platform dalam jaringan internet, interaksi dan fasilitas yang mendukung pelayanan belajar bagi mahasiswa (Anhusadar, 2020). Pemanfaatan media teknologi begitu luar biasa dalam proses pembelajaran secara daring sebagai alternatif solusi yang efektif bagi mahasiswa dan dosen dalam melaksanakan kuliah daring. "Faculty members should embrace technology and pay careful attention to student experiences to make the learning rich and effective" (Sahu, 2020). Awal semester ganjil tahun ajaran 2020/2021 sudah ada kebijakan dari pihak kampus IAIN Pontianak untuk menggunakan e-learning yang telah disediakan oleh pihak kampus akan tetapi karena dalam perjalanannya masih ada sistem yang belum sempurna sehingga dosen memilih alternatif yang dianggap memiliki karakteristik yang sama dengan e-learning dengan tetap memperhatikan capaian tujuan pembelajaran. Penerapan pembelajaran e-learning membutuhkan dukungan berupa fasilitas dan kebijakan yang dapat mendukung proses tersebut berjalan dengan baik (Fanny, 2019). Beberapa media daring yang digunakan dosen dalam perkuliahan antara lain: Google Meet, Google Classroom, Zoom Meeting, dan lain-lain.

Pada saat awal semester ganjil 2020/2021 peneliti melakukan pembelajaran daring dengan menggunakan aplikasi Google Meet. Aplikasi Google Meet memiliki ukuran yang ringan, sehingga dalam penggunaannya menjadi lebih cepat. Aplikasi ini juga sangat mudah digunakan sehingga bagi mahasiswa yang baru menggunakan aplikasi Google Meet tidak akan kesulitan. Fakta ini memperkuat bahwa Google Meet sangat diminati oleh banyak pengguna yang mulai merasakan dampak positif dari penggunaan aplikasi ini. Sejalan dengan yang disampaikan oleh Prihastanto (2020) bahwa kualitas kegunaan, kualitas informasi dan interaksi pelayanan website Google Meet berpengaruh signifikan terhadap kepuasan pengguna. Google meet juga dapat membantu pendidik dalam memberikan pembelajaran di masa pandemi. Sawitri (2020), Penggunaan Google Meet merupakan salah satu fitur dari google yang bisa dimanfaatkan untuk work from home saat social distancing untuk mencegah penyebaran virus Covid-19. Ia juga menambahkan bahwa "Google Meet bisa menjadi media alternatif untuk proses belajar mengajar". Proses perkuliahan pada mata kuliah metodologi penelitian kuantitatif dengan menggunakan aplikasi Google Meet sebagai alternatif dianggap mampu menjawab permasalahan yang ada selama kondisi pandemi saat ini. Google Meet dianggap sebagai media yang aman dalam pembelajaran online, dan sangat direkomendasikan selama wabah pandemi (Al-Maroof, Salloum, Hassanein, \& Shaalan, 2020). Sehingga peneliti tertarik melakukan sebuah penelitian terkait pembelajaran daring dengan menggunakan aplikasi Google Meet.

Ketika awal perkuliahan peneliti memberikan pretest berupa 20 butir dari 38 butir soal pilihan ganda yang telah dilakukan uji validitas dengan menggunakan korelasi bivariate pearson dan uji reliabilitas dengan guttman split-half coefficient berbantuan aplikasi SPSS versi 16. Tergambarkan dari data statistik deskriptif di atas menunjukkan bahwa rata-rata hasil belajar mahasiswa pada mata kuliah Metodologi Penelitian Kuantitatif menunjukkan hasil posttest lebih tinggi dibandingkan hasil pretest. Sejalan dengan penelitian yang dilakukan oleh Rusmansyah, Hayati, Winarti, \& Rahmi (2021) menyatakan bahwa penelitian yang dilakukan pada siswa SMA mengalami kenaikan yang besar pada posttest setelah digunakan media Google Meet. Selain itu didukung pula oleh penelitian yang dilakukan oleh Muniroh, Rojanah, \& Raharjo (2020) menyatakan bahwa hasil belajar siswa dengan menggunakan media aplikasi Google Meet lebih tinggi dibandingkan dengan hasil belajar siswa yang tidak menggunakan media aplikasi Google Meet. Penelitian lain yang relevan dengan penelitian ini adalah penelitian yang dilakukan oleh Aisyah \& Sari (2021), bahwa Google Meet memiliki pengaruh yang lebih efektif untuk meningkatkan hasil belajar siswa saat pembelajaran daring berlangsung. Hal ini menunjukkan bahwa aplikasi Google Meet dianggap efektif digunakan pada kondisi pembelajaran daring seperti saat ini. Hasil pengujian hipotesis juga menunjukkan bahwa terdapat pengaruh antara penggunaan aplikasi Google Meet terhadap hasil belajar mahasiswa pada mata kuliah Metodologi Penelitian Kuantitatif. Hal ini senada dengan penelitian yang dilakukan Rahayu \& Pahlevi (2021) menyatakan bahwa dari hasil pengujian hipotesis, analisis dan pembahasan adalah terdapat adanya pengaruh dari penggunaan media pembelajaran e-learning dengan Google Meet terhadap hasil belajar pada siswa kelas X-OTKP di SMK N 4 Surabaya. Adapun besar persentase pengaruh penggunaan aplikasi Google Meet sebesar $51.4 \%$ terlihat pada tabel model summary. Penggunaan Google Meet ternyata mampu menggantikan peran pembelajaran yang biasanya dilakukan di kelas melalui tatap muka, tanpa mengurangi esensi materi yang disampaikan. 
Seperti kita ketahui konsep dasar metodologi penelitian kuantitatif sangat penting untuk dipahami oleh mahasiswa apalagi dalam penyusunan skripsi. Dengan adanya aplikasi ini dosen dapat melakukan feedback kepada mahasiswa begitu juga sebaliknya.

Namun demikian, kegiatan pembelajaran pada mata kuliah metodologi penelitian kuantitatif di Program Studi Bimbingan Konseling Islam IAIN Pontianak menggunakan aplikasi Google Meet pada semester ganjil tahun ajaran 2020/2021 bukan tanpa kendala. Beberapa kendala yang fundamental adalah jaringan tidak stabil ketika kondisi cuaca hujan dan pada pertengahan perkuliahan ada mahasiswa yang left dari Google Meet karena kehabisan kuota. Hal ini sejalan dengan penelitian yang dilakukan oleh Prasetyono (2020) menyatakan bahwa penggunaan Google Meet dalam pembelajaran dari selama pandemi dalam pendidikan tinggi sangat membantu walaupun masih terkendala dan kekurangan dalam berbagai aspek, diantaranya adalah mereka kekurangan interaksi dalam pembelajaran daring karena tidak bisa kontak fisik dan mengalami kendala jika berkaitan dengan demonstrasi ataupun percontohan secara langsung. Adapun penelitian yang dihasilkan oleh Wiratama (2020) menyatakan bahwa evaluasi terhadap penggunaan Google Meet dalam perkuliahan daring setelah melalui 6 kali pertemuan mahasiswa menginginkan dapat belajar menggunakan metode luring. Menurut mahasiswa lebih mudah memahami materi perkuliahan jika dilakukan secara tatap muka Peneliti berasumsi dari kendala-kendala yang dialami mahasiswa tersebut sehingga tingkat keefektifitasan penggunaan aplikasi Google Meet hanya berada pada kategori cukup efektif. Adapun alternatif solusi yang diberikan adalah mengkombinasikan aplikasi Google Meet dengan aplikasi lain dalam pembelajaran daring sehingga hal-hal yang menjadi kendala yang dialami pada penggunaan aplikasi Google Meet dapat ditangguhkan oleh aplikasi lain. Hal ini sejalan dengan penelitian yang dilakukan oleh Basilaia \& Kvavadze (2020: 7) menyatakan bahwa "The teaching methodologies have to be studied and improved, including the available tools and platforms. We suggest that the Google Meet system be integrated to the google classroom platform, or the separate platform needs to be created for education purposes". Metodologi pembelajaran harus ditingkatkan termasuk platform yang digunakan. Pembelajaran dengan menggunakan platform Google Meet dapat diintegrasikan juga ke platform lain seperti google classroom guna untuk tercapainya tujuan pendidikan.

\section{PENUTUP}

Berdasarkan hasil penelitian dan pembahasan maka dapat ditarik kesimpulan bahwa penggunaan aplikasi Google Meet memiliki pengaruh yang signifikan terhadap hasil belajar mahasiswa Program Studi Bimbingan Konseling Islam IAIN Pontianak kelas VA terlihat dari ratarata keseluruhan hasil posttest lebih besar dibandingkan nilai rata-rata keseluruhan hasil pretest. Akan tetapi, berdasarkan kategori tafsiran efektivitas Normalized Gain menunjukkan nilai rata-rata hasil belajar mahasiswa hanya berada pada kategori cukup efektif. Kegiatan pembelajaran pada mata kuliah metodologi penelitian kuantitatif di Program Studi Bimbingan Konseling Islam IAIN Pontianak menggunakan aplikasi Google Meet pada semester ganjil tahun ajaran 2020/2021 berlangsung relatif kondusif walaupun memiliki beberapa kendala seperti: jaringan tidak stabil ketika kondisi cuaca sedang hujan, pada pertengahan perkuliahan ada mahasiswa yang left dari Google Meet karena kehabisan kuota, dan lain-lain.

Adapun alternatif solusi yang diberikan adalah mengkombinasikan aplikasi Google Meet dengan aplikasi lain dalam pembelajaran daring sehingga hal-hal yang menjadi kendala yang dialami pada penggunaan aplikasi Google Meet dapat ditangguhkan oleh aplikasi lain.

\section{DAFTAR PUSTAKA}

Aisyah, S., \& Sari, D.I. (2021). Efektivitas penggunaan platform google meet terhadap hasil belajar siswa. Mathematic Education Journal, 4(1): 45-49.

Al-Maroof, R.S., Salloum, S.A., Hassanien, A.E., \& Shaalan, K. (2020). Fear from covid-19 and technology adoption: the impact of google meet during coronavirus pandemic. Interactive Learning Environments, 1-16. DOI: 10.1080/10494820.2020.1830121. 
Anhusadar, L. O. (2020) Persepsi mahasiswa piaud terhadap kuliah online di masa pandemi. kindergarten: Journal of Islamic Early Childhood Education, 3(1), 44-58.

Basilaia, G., \& Kvavadze, D. (2020). Transition to online education in schools during a sars-cov-2 coronavirus (covid-19) pandemic in Georgia. Pedagogical Research, 5(4), em0060. https://doi.org/10.29333/pr/7937.

Basilaia, G., Dgebuadze, M., Kantaria, M., \& Chokhonelidze, G. (2020). Replacing the classic learning form at universities as an immediate response to the covid-19 virus infection in Georgia. International Journal for Research in Applied Science \& Engineering Technology (Ijraset), 8(III), 101-108. Https://Doi.Org/10.22214/Ijraset.2020.3021.

Burgess, S., \& Sievertsen, H. H. (01/04/2020). Schools, skills, and learning: the impact of covid-19 on education. Web Publications. Retrieved 05 March 2021, from Https://Voxeu.Org/Article/Impact-Covid-19-Education.

Daheri, M., Jualiana., Deriwanto., \& Amda, A. D. (2020). Efektifitas whatsapp sebagai media belajar daring. Jurnal Basicedu, 4(4), 775-783. doi: 10.31004/basicedu.v4i4.445.

Fanny, A. M. (2019). Pengaruh pembelajaran e-learning terhadap hasil belajar mahasiswa pgsd pada mata kuliah konsep ips lanjut. Jurnal Inventa, 3(1), 130-135.

Gewin, V. (2020). Five tips for moving teaching online as covid-19 takes hold. Nature, 580, 295-296. Doi:10.1038/D41586-020-00896-7.

Ghufron, M.A. (2018). Revolusi industri 4.0: Tantangan, peluang dan solusi bagi dunia pendidikan. Seminar Nasional dan Diskusi Panel Multidisiplin Hasil Penelitian \& Pengabdian kepada Masyarakat. 332-337.

Greenstein, L. (2012). Assessing 21st century skills: A guide to evaluating mastery and authentic learning. Thousand Oaks: Corwin.

Hake, R.R. (1999). Analyzing change/gain scores. Woodland Hills: Dept of Physics, Indiana University.

Johnson, N., Veletsianos, G., \& Seaman, J. (2020). U.S. faculty and administrators' experiences and approaches in the early weeks of the covid-19 pandemic. Online Learning, 24(2). https://doi.org/10.24059/olj.v24i2.2285.

Mardiah, S. (2020). Students' perception on the use of whatsapp application in teaching of english at eight grade students' of madrasah tsanawiyah nurul hidayah bhakti idaman Tanjab Timur Jambi (Tesis). Jambi: State Islamic University Sulthan Thaha Saifuddin Jambi.

Menristekdikti. (17/01/2018). Pengembangan iptek dan pendidikan tinggi di era revolusi industri 4.0. Reference list: Electronic sources (web publications). Retrieved 14 February 2021, from https://www.ristekdikti.go.id/kabar/pengembangan-iptekdan-pendidikan-tinggi-di-erarevolusi-industri-4-0-2/.

Muniroh, S. H., Rojanah, S., \& Raharjo, S. (2020). Efektivitas pembelajaran matematika melalui media google meet ditinjau dari hasil belajar siswa di masa pandemi. Edisi: Jurnal Edukasi dan Sains, 2(2), 410-419.

Nuriansyah, F. (2020). Efektivitas penggunaan media online dalam meningkatkan hasil belajar pada mahasiswa pendidikan ekonomi saat awal pandemic covid-19. Jurnal Pendidikan Ekonomi Indonesia, 1(2), 61-65.

Prasetyono, R. N. (2020). Analisis penggunaan google meet berbasis android mobile dalam minat belajar mahasiswa informatika. Indonesian Journal of Informatics and Research, 1 (2), 84-90.

Prihastanto. (2020). Analisis kualitas aplikasi google meet pada proses kegiatan rapat dan kegiatan pembelajaran menggunakan metode webqual 4.0. Journal of Computer Engineering System and Science, 10(2), 5-12.

Rahayu, S., \& Pahlevi, T. (2021). Pengaruh media pembelajaran e-learning dengan google meet terhadap hasil belajar siswa. Jurnal Penelitian dan Pengembangan Pendidikan, 5(1), 91-99.

Rusmansyah, N Hayati, A Winarti, and Rahmi. (2021). Train students' science process skills and selfefficacy in online learning using the scientific critical thinking (SCT) model assisted by google classroom and google meet. Journal of Physics: Conference Series, 1-8. https://doi.org/10.1088/1742-6596/1760/1/012034. 


\section{Jurnal Penelitian Ilmu Pendidikan, 14 (2), 2021 - 147 \\ Prisuna}

Sahu, P. (2020). Closure of universities due to coronavirus disease 2019 (covid-19): Impact on education and mental health of students and academic Staff. Cureus, 12(4). Doi: $10.7759 /$ Cureus.7541.

Sawitri, D. (2020). Penggunaan google meet untuk work from home di era pandemi coronavirus disease 2019 (covid-19). Jurnal Prioritas: Jurnal Pengabdian Masyarakat, 2(1), 13-21.

Setyawan, A., Aznam, N., Paidi., Citrawati, T., \& Kusdianto. (2020). Effects of the google meet assisted method of learning on building student knowledge and learning outcomes. Universal Journal of Educational Research, 8(9), 3924-3936. doi: 10.13189/ujer.2020.0809017.

Sugiyono. (2008). Metodologi penelitian pendidikan (Pendekatan kuantitatif, kualitatif, dan $r \& d$ ). Bandung: Alfabeta.

Sugiyono. (2011). Metodologi penelitian kombinasi (Mixed methods). Bandung: Alfabeta.

Surat Edaran Mendikbud RI 2020 No. 4, Pelaksanaan kebijakan pendidikan dalam masa darurat penyebaran covid- 19 .

Undang-undang RI 2003 No. 20, Sistem pendidikan nasional.

UNESCO. (24/03/2020). Covid-19 educational disruption and response. Web Publications. Retrieved 10 March 2021, from Https://En.Unesco.Org/Covid19/Educationresponse/.

Vokatis, B., \& Zhang, J. (2016). The professional identity of three innovative teachers engaging in sustained knowledge building using technology. Frontline Learning Research, 4(1), 58-77. http://dx.doi.org/10.14786/flr.v4i1.223.

Wikipedia. (12/02/2021). Google meet. Web Publications. Retrieved 14 February 2021, from https://en.wikipedia.org/wiki/Google_Meet.

Wiratama, N.A. (2020). Penerapan google meet dalam perkuliahan daring mahasiswa pgsd pada mata kuliah konsep dasar pkn sd saat pandemi covid 19. Journal of Teaching in Elementary Education, 4(2). doi: http://dx.doi.org/10.30587/jtiee.v4i2.2152.

Zhang, W., Wang, Y., Yang, L., \& Wang, C. (2020). Suspending classes without stopping learning: China's education emergency management policy in the covid-19 outbreak. Journal of Risk and Financial Management, 13(3), 1-6. https://doi.org/10.3390/jrfm13030055. 